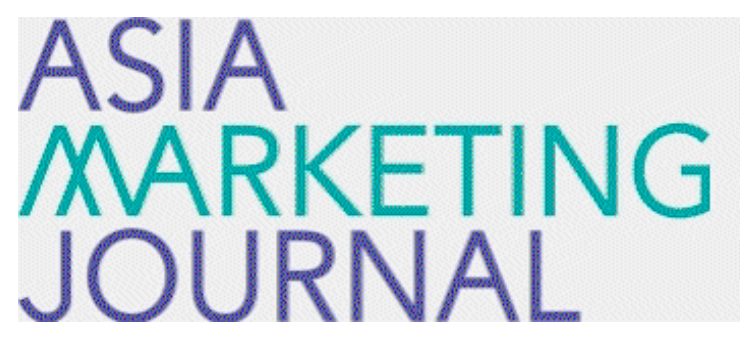

ASIA MARKETING JOURNAL

Volume 3 | Issue 4

Article 3

$12-1-2001$

\title{
제품평가에 있어서 전문성에 따른 단서효과
}

Nak Hwan Choi

Jin Ryeol Lee

Kwang Jin $\mathrm{Na}$

Follow this and additional works at: https://amj.kma.re.kr/journal

Part of the Marketing Commons

\section{Recommended Citation}

Choi, Nak Hwan; Lee, Jin Ryeol; and Na, Kwang Jin (2001) "제품평가에 있어서 전문 성에 따른 단서표과," Asia Marketing Journal: Vol. 3 : Iss. 4 , Article 3.

Available at: https://doi.org/10.53728/2765-6500.1075

This Article is brought to you for free and open access by Asia Marketing Journal. It has been accepted for inclusion in Asia Marketing Journal by an authorized editor of Asia Marketing Journal. 


\title{
제품평가에 있어서 전문성에 따른 단서효과*
}

\section{Cue Effects in Product Evaluation According to Expertise}

\author{
최낙환(전북대학교 경영학부 교수) \\ cnhemoak. chonbuk.ac. $\mathrm{kr}$ \\ 이진렬(조선대학교 디자인학부 전임강사) \\ bayhuntechosun.ac.kr \\ 나광진(전북대학교 경영학부 강사) \\ jinny5322@hanmail.net
}

\begin{abstract}
본 연구는 소비자들이 제품을 평가하는 과정에서 각 유형의 단서정보들이 평가과정에 어 떻게 영향을 주는지를 살펴 봄으로써, 이론적으로는 정보단서와 관련하여 소비자의 제품평 가 및 판단과정을 설명하는 기본적인 틀을 제시하고, 이를 통해 기업의 마케팅 및 광고전략 에 대한 관리적 시사점을 제공하였다. 본 연구에서 이용된 단서의 유형은 외재적 단서 (extrinsic cues)와 내재적 단서(intrinsic cues)를 이용하였다(Olson 1972; Olson and Jacoby 1973). 분석결과에 따르면 비전문가의 경우 내재적 단서는 제품평가에 영향을 미치지 못하지만 외재적 단서는 제품평가를 좀 더 우호적으로 수행하는 역할을 하였다. 이와는 달리 전문가 는 외재적 단서가 아닌 내재적 단서가 제품평가에 영향을 미치는 것으로 나타났다. 그리고 전문가는 내재적 단서 관련 사고를 더 많이 하며 강한 내재적 단서예 접근 가능할수록 그 성향이 중가하나 비전문가의 경우에는 외재적 단서 관련 사고를 더 많이 함으로써 외재적 단서를 더 많이 처리한다. 그러나 비전문가는 전문가와는 달리 외재적 단서의 강도가 단서 관련 사고의 수를 중가시키지는 않는 것을 알 수 있다. 또한 전문가는 내재적 단서관련사고 의 우호성이, 반대로 비전문가는 외재적 단서관련사고의 우호성이 제품평가에 미치는 영향 을 매개하는 것으로 나타넜다.

이러한 연구결과는 소비자의 재품평가과정에서 단서의 효과에 따른 영향을 제시해주는 유 용한 개념적인 틀이 될 것이며 향후 연구에서 다양한 확장연구가 필요할 것이다.
\end{abstract}

* 논문접수 : 02.02 게재확정 : 02.05 


\section{1. 서 론}

제품이란 효용의 묶음 또는 조합을 의미하며, 효용을 제공함으로써 구입하는 사랍의 욕구 나 필요를 충족시켜줄 수 있는 모든 것이 제품의 범주에 포함된다고 볼 수 있다. 따라서 시 장에서 교환되고 소비되는 대상은 어느 것이라도 제품이라고 할 수 있으며, 나쁜 제품으로 는 어떤 마케팅전략을 사용하더라도 결코 지속적으로 사랑을 받을 수 없기 때문에 좋은 제 품이라는 것은 마케팅성공의 충분조건은 아니지만 필요조건은 될 수 있다.

제품의 형태에는 여러 가지가 있다. 여기에는 물리적 대상물 뿐 아니라 서비스, 사람, 장 소, 조직, 아이디어 등이 포함된다. 삼성의 $\mathrm{CD}$ 플레이어, 코렉스의 자전거 둥 대부분의 제품 이 유형제품이지만, 미용실에서의 혜어컷이나 옴악 콘서트, 제주도에서의 휴가, 영화나 연극 공연, 세무사의 세금에 대한 카운셀링과 같은 무형의 제품도 있는 것이다. 지우개와 같은 단 순한 기능만 하는 제품이 있는가 하면 자동차와 같이 많온 부속품, 애프터서비스 둥이 결합 되어 하나의 제품올 만드는 경우도 있다.

기업과 소비자률 연결하는 역할을 하는 제품은 기업과 소비자의 입장에서 각기 다른 측면 을 가질 수 있으며 각각의 입장에 따라 제품의 의미는 조금씩 달라지게 된다. 그러나 중요 한 것은 보다 많은 마케팅 기희를 포착하고 성공을 거두기 위해 기업은 소비자의 관점에서 제품을 정의하고 그 의미를 이해해야 할 필요가 있다.

이러한 제품에 대하여 소비자는 시장에 존재하는 다양한 대안상표중에서 하나를 선택함에 있어 선택이전에 평가과정을 거치게 된다. 따라서 다양한 경쟁대안중에 하나률 선택하는 과 정에 있어서 소비자는 제품의 성능, 좀 더 일반적으로 말하자면 품질에 대한 불확실성이라 는 문제에 직면하게 된다. 이 과정에서 소비자는 여러 가지 대안들을 충분히 검색할 시간도 부족하거니와 또한 가능한 모든 대안을 평가하려는 모티브도 부족하기 때문에 경쟁대안의 제품들의 품질올 평가하는데 있어서 휴리스틱(heuristic)에 의존하는 성향을 갖는다. 경제학자 들 뿐만 아니라 마케팅분야에서도 소비자들은 제품의 품질올 평가하는데 있어서 제품의 시 그널(signal)을 휴리스틱으로 사용하는데 특히 (1) 구매에 대한 지각된 위험을 감소시킬 필요 가 있을 경우(Jacoby, Olson, and Haddock 1971), (2) 소비자가 제품에 대한 전문성이 부족하고 결과적으로 품질을 평가할 수 있는 능력이 부족한 경우(Rao and Monroe 1988), (3) 소비자의 관여도가 낮은 경우(Celci and Olson 1988), (4) 평가대상의 품질이 평가하기에 너무 복잡하거 나 또는 소비자가 품질을 평가하는데 있어서 충분한 시간울 소비하려는 경향을 갖지 않는 경우(Allison and Uhl 1964), 또는 (5) 정보탐색욕구와 정보에 대한 욕구가 있는 경우(Nelson 1970) 둥에 휴리스틱을 사용하는 경향이 있다.

여기에서 가장 널리 이용되는 제품품질의 시그널로서는 상표명(Darby and Karni 1973), 상표 광고(Milgrom and Roberts 1986), 제품의 물리적 외형(Nelson 1970), 가격(Leavitt 1954; Milgrom and Roberts 1986; Olson 1972, Wolinsky 1987), 제품/제품명성, 판매점포명, 품질보증(Rao and Monroe 1989) 등이 있다.

일반화된 결과는 아니지만, 품질에 대한 시그녈로써 대개 상표명은 가격보다 중요하고 가 격은 물리적 외형보다 중요하고, 소매상의 명성이나 점포명은 제품 품질에 대한 시그널이지 만 상표나 가격보다는 덜 중요한 것으로 나타난다(Jacoby, Szybillo, and Busato-Schach 1977; Rao and Monroe 1989). 이러한 시그널로서의 상대적 중요성은 보통 톡이성에 의한 것으로 경쟁제 품과는 공유될 수 없는 것이다. 예를 들어, 상표명은 전형적으로 제품의 경쟁적인 범주 안에 서 소수의 제품에만 사용하기 때문에 매우 특별한 시그널이 된다. 반면에 가격과 물리적 외 
형의 신호는 경쟁적인 제품간에 매우 널리 사용되어지기 때문에 상표보다는 덜 특별한 시그 널이 된다. 소매상의 명성은 가격보다 덜 중요한 시그널이다. 왜냐 하면 전형적인 소매상의 명성은 다양한 경쟁제품을 취급하고, 이는 상대적으로 다양한 품질의 범주를 갖고 있기 때 문이다.

이처럼 제품의 품질평가에 대한 시그널로서 마케팅과 경제학분야에서 주로 관심을 받아온 요인들은 상표, 가격, 물리적 외형 및 판매점포의 명성 등이 있다(Milgrom and Roberts 1986; Rao and Monroe 1989; Wolinsky 1987). 그러나 이와 관련하여 Rao and Monore(1989)는 20년 동안 의 연구에서 시그널사용에 대한 중요성, 일반화 및 통계적 유의성에 대한 믿을 만한 연구가 없었다고 주장하였으며, 더구나 마케팅분야에서 조차도 이에 대한 종합적인 프레임웍을 제 시하지 못함으로써 소비자의 제품평가과정울 연구하는데 있어서 미홉한 실정이다.

이와 관련하여 본 연구는 제품의 시그널들이 소비자의 제품평가과정에 어떻게 작용하는지 를 체계적으로 검중하고자 한다. 이를 위해 먼저 소비자의 제품평가과정에 사용되는 시그널 에 대한 분류가 필요하다.

일반적으로 소비자가 상표룔 평가할 때 이용하는 기준에는 외재적 단서(extrinsic cues)와 내재적 단서(intrinsic cues)가 있다(Olson 1972; Olson and Jacoby 1973). 상표의 외재적 단서는 제 품의 물리적인 부분이 아니면서 제품과 관련된 속성들로서 상표명, 포장, 가격, 점포명 둥이 며, 내재적 단서는 판매상품의 물리적 속성으로서 제품의 물리적인 톡성을 변화시키지 않고 는 조정될 수 없는 제품의 구성요소이다. 이러한 단서들은 상표의 품질과 관련되어 있다.

현실적인 시장환경에서 제품의 노출시점에는 내재적 단서와 외재적 단서가 동시에 주어지 는 경우가 많다. 예를 들어 제품의 가격이나 포장 또는 판매점포 및 속성정보 등이 동시에 주어지는 경우이다. 그러나 아직까지 소비자의 제품평가과정에서 품질평가의 시그널로서 외 재적 단서와 내재적 단서의 작용에 관한 일반화된 결론을 제시하지 못하고 있는 실정이다. 예를 들어 일부 연구에서는 내재적 단서 혹은 외재적 단서를 차별화시켜 독립적인 효과들을 검중하고있다. 이와 관련하여 이미현 \& 임숙자(1999, 2001)는 가격, 상표, 상점 등의 외재적 단서가 제품의 품질지각, 가치지각 및 구매의도에 영향을 미치며 이들 세 단서들이 서로 상 호작용한다고 제시하고 있다. 이수열 \& 황창규(1995)는 호텔서비스를 대상으로 서비스품질 지각에 대한 외재적 단서의 효과에서 제품인 경우 가격이 소비자의 평가에 상대적으로 큰 영향을 미치지만 서비스인 경우에는 물리적 환경과 같은 외재적 단서가 더 큰 영향을 미친 다고 제시하였다. 이 이외에도 김가영(1998)은 외재적 단서중 가격이 제품의 품질지각에 가 장 큰 영향을 미친다고 제시하였다. 또한 일부 연구(김영국 1992)에서는 기존의 정교화가능 성모델(Petty \& Cacioppo 1981)을 바탕으로 하여 제품을 관여수준에 따라 분류한 다음 주변적 단서효과가 소비자의 평가에 어떠한 영향을 미치는지를 파악함으로써 정교화가능성모델에 대한 검중을 수행하였다.

이와 같은 기존 연구들은 외재적 단서와 내재적 단서가 동시에 제공되는 마케팅프로모션 상황에서 이들 두 단서의 유형이 소비자의 평가에 어떠한 영향을 미치는 지를 체계적으로 검중하지 못하고 있으며 또한 정교화가눙성모델에서 제시하는 것과는 달리 전문성과 같이 소비자의 정보탐색과정에 영향을 미치는 소비자의 특성변수률 고려하지 않고 변수자체의 독 립적인 결과를 제시하고 있다. 이러한 기존연구들은 실제 시장상황에서 제품과 관련된 여러 유형의 단서들이 소비자의 실제 제품평가과정에 어떠한 영향을 미치는지 체계적으로 검중하 지 못함으로써 단서의 효과를 이해하는데 있어서 유용한 통찰력을 제시하지 못하고 있다. 따라서 본 연구에서는 소비자의 제품평가과정에서 외재적 단서와 내재적 단서를 동시에 고

\section{0 안국마케링저녈 제 3 권 4 호}


려하고 또한 정보탐색과정에 영향을 미치는 전문성과 같은 소비자의 톡성변수률 퉁해 검중 함으로써 각 단서의 유형이 소비자의 제품평가과정에 어떠한 영향을 미치는지를 살펴보고자 한다. 이와 같은 논의를 바탕으로 하여 본 연구의 목적을 다음과 같이 설정하였다.

첫째, 제품평가에 대한 시그널로서 외재적 단서(정보)들과 내재적 단서(정보)들을 이론적 으로 탐색한다.

둘째, 소비자의 전문성수준에 따라 외재적 단서와 내재적 단서가 강하게 주어지는 경우와 약하게 주어지는 경우에 제품평가과정에 차이가 있는지를 검중한다.

셋째, 본 연구결과를 토대로 기업들이 내재적 단서들과 외재적 단서들을 활용하여 효과적 인 제품촉진전략올 구축하기 위한 관리적 시사점들을 제시한다.

\section{2. 이론적 배경}

\section{1. 단서이론}

단서효용이론(cue utilization theory)은 소비자가 제품의 품질에 대한 지각을 평가하는 데 있 어서 효과적인 프레임웍을 제공해 줄 수 있다. 단서효용이론에 따르면 모든 제품은 소비자 가 그 제품에 대하여 품질의 대리적 척도로서 여길 수 있는 일련의 단서로 구성되어 있다고 제시하고 있다(Cox 1967; Olson 1972). 제품의 품질평가에 있어서 단서는 제품에 대한 소비자 의 예측적 가치(predictive value)와 확신성 가치(confidence value)에 따라 환기되어 진다. 가치 의 예측적 가치는 소비자가 특정 단서를 제품의 품질과 연관시키는 정도이다. 이것은 단서 의 진단성(diagnosticity) 개념과 유사하다고 할 수 있는 것으로 그 단서를 이용하게 됨으로써 성공적인 과업해결을 할 것이라는 신뢰성과 가능성을 표현한다고 볼 수 있다(Dick, Chakravariti, and Biehal 1990). 단서의 확신성가치는 소비자가 그러한 단서를 정확하게 사용하 고 판단할 수 있는 자신들의 능력에 있어서 확신을 갖는 정도이다(Cox 1967; Olson 1972). 이 렇게 높은 확신성가치와 높은 예측적 가치로 특징지워지는 단서들은 품질평가과정에서 가장 중요한 역할을 수행한다.

이러한 단서(cues)는 외재적 단서(extrinsic cues)와 내재적 단서(intrinsic cues)로 분류될 수 있다(Olson 1972; Olson and Jacoby 1973). 외재적 단서는 제품과 관련된 속성으로 제품 그 자체 와는 관련이 없는 것이다. 기존 연구에서는 이러한 외재적 단서에 관한 연구를 통하여 다양 한 유형의 외재적 단서를 제시하고 있다. 기존연구에서 밝혀진 이러한 외재적 단서와 관련 하여 소비자가 제품을 평가함에 있어서 가격(Leavitt 1954), 브랜드명(Allison and Uhl 1964), 포 장(McDaniel and Baker 1977), 점포명(Wheatley, Chiu, and Goldman 1977), 색깔(Peterson 1977), 외 형(Olson 1972)과 같은 외재적 단서를 이용한다고 제시하고 있다.

이와는 달리 내재적 단서는 제품 그 자체와 관련된 단서로, 제품 그 자체의 특성을 변화 시키지 않고는 조정될 수 없는 제품의 구성요소로서 맛, 질감, 향기, 성능둥을 포함한 그 제 품의 속성과 직접적으로 관련된 단서이다(Olson 1976).

기존 연구에서는 소비자가 제품의 품질을 평가하는데 있어서 이러한 내재적 단서와 외재 적 단서 모두를 이용한다고 제시하고 있다(Jacoby, Olson, and Haddock 1971; Simonson 1989; Szybillo and Jocoby 1974). 특히 확장상표의 평가에 있어서 모상표는 외재적 단서로 그리고 속 
성정보와 같이 제품 그 자체에 관련된 정보는 내재적 단서로 작용한다.

\section{2. 전문성}

\subsection{1. 전문성의 개념}

어떤 문제에 직면할 때 그 문제에 대한 지식이 많은 전문가(expert)와 지식이 적은 비전 문가(novice)는 문제해졀과정에서 차이가 있다. 소비자의 지식(knowledge)은 소비자들이 제품과 관련하여 가지고 있는 정보, 경험 및 친숙성의 정도를 말한다(Duhan, Johnson, Wilcox and Harrell 1997). 소비자의 지식에 관한 연구는 마케팅분야에서 폭넓게 전개되어 져 왔는데(Alba and Hutchinson 1987; Brucks 1985) 일반적으로 기억으로부터 인출 가능 한 것 또는 제품에 대한 외부적 탐색이 발생하기에 앞서 일반적으로 인출되는 정보로서 알 려져 있다. 이러한 소비자의 사전지식은 정보의 탐색과 정보의 처리 같은 소비자행동을 이 해하는데 있어 하나의 중요한 구조로서 이해되고 있다.

\subsection{2. 전문성의 유형}

일반적으로 제품에 대한 지식의 유형은 객관적 지식(objective knowledge)과 주관적 지 식(subjective knowledge), 경협에 의한 지식(experience-based prior knowledge)으로 나 누어 진다(Duhan et al. 1997).

소비자의 객관적 지식수준은 소비자의 기억 속에서 실제 저장되어 있는 것을 의미하기 때 문에 객관적 지식은 Alba et al.(1987)의 전문성 또는 제품과 관련된 과업을 수행하는 능력이 라고 부르는 것과 아주 밀접한 관련이 있다. Brucks(1985)는 전문적 용어, 제품속성평가의 기 준, 속성간의 지각된 공변성, 여러 가지 속성들의 중요성올 결정하는 상황적 요인들을 다루 는데 있어서 객관적 지식의 다양한 측면올 묘사하였다. 높은 객관적 지식수준의 효과는 새 로운 정보를 더 쉽게 처리하고 이에 따라 제품을 평가하는 능력도 더 향상되게 된다. 또 한 높은 지식수준을 가지고 있는 소비자들은 잘 개발된 지식구조를 가지고 있고 이해할 수 있 는 늉력이 빠르며 낮은 지식수준을 가지고 있는 소비자들보다도 더 눱게 정보를 조직화하게 된다(Chase and Simon 1973). Miyake와 Norman(1979)은 낮은 지식수준을 가지고 있는 소비자들 은 사물을 파악하는 어려움에 대하여 많은 질문을 하지 않았는데 이는 그들이 답을 이해하 는 눙력올 가지지 못했다는 것을 스스로 인식했기 때문에 이러한 현상이 발생한다고 결론지 었다.

소비자의 주관적 지식은 자기지식수준의 충분성에 대한 자신감으로서 묘사되고 있으며 (Brucks 1985), 대부분의 연구들은 소비자들의 자기평가에 의한 지식이 항상 자신의 실제 지 식과 일치하지는 않는다고 하였다(Schacter 1983). Park et al.(1994)은 주관적 지식이 소비자의 제품에 대한 과거 경험과 강하게 관련성이 있다는 것을 발견하였고, Park and Lessig(1981)는 자신감과 밀접하게 관련되어 있다고 하였다. 따라서 주관적 지식이 높다는 의미는 소비자가 제품평가와 관련하여 제품과 관련된 과업들을 수행할 능력 또는 자신감이 높다는 것을 말한 다(Duncan and Olshavsky 1982). 또 다른 연구에서는 낮은 주관적 지식을 가지고 있는 소비자 들은 제품에 관한 정보탐색의 정도도 낮다는 것을 밝혔다(Urbany, Kickson, and Wilkie 1986). 따라서 높은 주관적 지식은 더 높은 정보탐색능력과 제품평가능력에 관련이 있음을 알 수 있다. 또한 Brucks(1985), Johnson and Russo(1984)등도 지식이 새로운 정보를 처리하는 능력 및 처리된 정보의 효율성 등에도 긍정적으로 관련이 있음을 발견하였다. 
경헙에 근거한 지식은 제품과 관련된 친숙성의 3가지 구성요소로서 정의할 수 있는데 이 들은 제품의 탐색경헙, 사용경헙 그리고 실제 소유경헙이다(Park and Lessig 1981). Alba와 Hutchinson(1987)은 이러한 경험적 감각으로서 친숙성(familiarity)이라는 용어률 사용하였는데 이를 경험에 의해 축적된 제품관련 경헙의 양이라고 정의하고 있다.

\section{3. 연구 1}

앞에서 살펴본 이론적 고찰을 통하여 연구 1 에서는 외재적 단서와 내재적 단서가 소비자 의 제품평가에 미치는 영향을 상표위계에 따라 그리고 전문성에 따라 어떻게 다르게 나타나 는지를 검중하고자 한다. 이를 위하여 가설을 설정한 다음 실중분석을 통해 검토하고자 한 다.

\section{1. 전문성에 따른 단서의 효과에 대한 가설의 설정}

소비자들이 제품을 톡정 범주로 범주화하고 범주에 관해 체계화된 지식(스키마)을 적용한 다는 것은 잘 알려져 있다(Meyers-Levy and Tybout 1989; Sujan 1985). 대부분 스키마는 객관적 인 속성과 같은 내재적 단서를 기초로 하고 있다. 예를 들어 사륜구동기어를 장착한 차량은 경차가 아니며 사륜구동형 차량에 범주화시킬 것이다. 그러나 외재적 단서를 기초로 한 스 키마(예를 들어, 후광효과의 원천을 들 수 있는데 이는 외재적 단서를 기초로 한 것임)는 그 다지 객관적이지 못한 속성을 기초로 형성된다. 그들은 추론에 근거하거나 상황의존적이며 범주 구성원에 걸쳐 다양하게 서로 다르게 나타나는 속성에 기초한다. 예를 들어 소비자들 은 특정 기업의 브랜드명과 같은 외재적 단서를 가진 제품에 대해 잘 개발된 고정관념을 가 질 수 있다(Hong and Wyer 1989, 1990). 이러한 외재적 단서에 기초한 범주들(예를 들어, 톡정 브랜드는 믿올 만 한다)은 정확하지 못하고, 상황의존적이며 상황에 따라 변하는 기준을 기 초로 하는 지식구조를 나타낸다. 모든 특정브랜드가 믿을 만 하다는 고정관념은 제품에 대 한 신뢰성 있는 관찰보다는 추론에 기초한다.

전문가들은 고정관념으로서의 외재적 정보와 내재적 정보를 모두 사용할 수 있는 반면 비 전문가들은 외재적 정보에 의존할 것으로 보인다(Alba and Hutchinson 1987; Sujan 1985). 전문 가와 비전문가는 우호적 및 비우호적인 내재적 단서와 함께 우호적이거나 비우호적인 외재 적 단서에 모두 노출되었을 경우에 제품의 평가과정은 다를 것으로 예상된다. 전문가들은 그들에게 제시된 모든 정보에 포괄적인 처리를 할 것으로 기대된다(Maheswaran and Sternthal 1990). 따라서 전문가는 외재적 단서정보 하나만 탐색하기보다는 제품의 평가에 더 진단적 이라고 생각하는 내재적 단서정보를 더 자세히 탐색할 것으로 예상된다. 이러한 자세한 내 재적 단서정보탐색과정은 내재적 단서정보의 강도가 클 때 제품평가에 대한 평가가 더 우호 적일 것으로 예상된다. 이 경우 전문가는 외재적 단서정보의 관련성과 중요성을 줄이고 내 재적 단서정보만을 제품평가에 이용할 것으로 예상된다.

이와는 반대로 비전문가들은 외재적 단서정보를 초기에 처리하고 그 결과에 따라 제품평 가를 수행할 것으로 예상된다. 비록 비전문가는 내재적 단서정보를 처리한다고 할 지라도 그러한 정보처리과정에 정교화를 하지 않을 것이며 따라서 그러한 내재적 단서정보의 영향 
은 아주 미홉하고 결과적으로 외재적 단서정보만이 제품평가에 영향을 미칠 것으로 예상된 다. 이를 바탕으로 하여 다음 가설올 설정하였다.

가설 1 : 전운성수준에 따라서 제품평가에 대한 외재적 단서와 내재적 단서의 효과는 다 를 것이다.

가설 1-1: 전운가는 내재적 단서정보가 강할 때 제풀명가률 더욱 긍정적으로 할 것이 다. 외재적 단서정보의 강도는 전문가의 평가에 영향율 미치지 못할 것이다.

가설 1-2: 비전문가는 외재적 단서정보가 강할 때 제품평가를 더욱 긍정적으로 할 것 이다. 내재적 단서정보의 강도는 비전문가의 평가에 영향을 미치지 못할 것이다.

\section{2. 연구의 대상 및 절차}

본 연구의 실헙자극으로서 김치냉장고를 이용하고 있거나 또는 김치냉장고에 관심이 있는 소비자 247 명이 설문조사에 참가하여 세 가지 형태의 설문에 무작위로 할당되었다. 이들을 집단A,B 및 $\mathrm{C}$ 로 분류하였다. 이들 소비자는 국내 $\mathrm{C}$ 대학의 여학생만을 대상으로 무작위추 출(random sampling)을 통해 선정되었다. 설문융답자를 실제 주부로 하지 않고 대학생으 로 한 것은 현재 김치냉장고가 보편화되어 있어 실제 주부들이 김치냉장고에 대한 속성들을 잘 알고 있기 때문에 본 연구에서 살펴보고자 하는 전문가와 비전문가로 구분하기 어려울 수 있으며 따라서 전문성에 따른 효과를 검중하지 못할 가능성이 있기 때문이다. 반면 가정 에서 김치냉장고를 이용하는 경우에는 가족구성원들이 김치냉장고를 합께 이용하기 때문에 김치냉장고를 이용하는 가정과 이용하지 않는 가정에서의 가족구성원으로서 대학생들이 전 문가와 비전문가로 더욱 뚜렷하게 구분될 것으로 판단된다.

집단 $\mathrm{A}$ 는 자극으로서 제시된 제품에 대한 정보에 있어서 상대적으로 약한 외재적 및 내 재적 단서가 제시되었다. 집단 $\mathrm{B}$ 는 약한 외재적 단서와 강한 내재적 단서가 제시되었으며 반대로 집단 $\mathrm{C}$ 는 강한 외재적 단서와 약한 내재적 단서가 제시되었다. 이들 세 개의 집단에 포함된 피실험자들은 실험자가 제시하는 각각 다른 형태의 자극에 노출된 후 제품평가에 대 한 관련문항과 전문성수준을 묻는 문항에 웅답하였다.

본 연구는 현재 모 중소기업이 생산하여 판매하고 있는 김치냉장고(상표명 : fresh)를 실험 자극으로 이용하였으며 외재적 단서로서는 브랜드, 가격, 포장방법 및 판매점포명이 그리고 내재적 단서로서는 속성관련정보가 이용되었다. 각 실헙자들은 외재적 및 내재적 단서로서 의 속성정보가 함께 제시된 fresh에 대한 광고지, 즉 실헙자극이 제시되었다.

실험자극에 이용된 외재적 및 내재적 단서정보는 관련잡지로부터 얻은 정보와 토론을 퉁 한 추가정보롤 통해 수집되었다. 먼저 외재적 단서로는 브랜드, 가격수준, 포장방법 및 판매 점포명이 이용되었는데 브랜드의 경우 대기업브랜드와 중소기업브랜드로 단서의 강도를 조 정하였고 가격수준의 경우 상대적으로 높은 가격수준과 타기업 제품과 동일한 가격으로 단 서의 강도를 조정하였다. 포장방법의 경우에는 충격완화를 위한 특수포장과 산업표준에 명 시된 포장방식으로 단서의 강도를 조정하였고 또한 반매점포는 현대백화점과 $\mathrm{E}$ 마트로 단서 의 강도를 조정하였다. 이러한 외재적 단서강도의 조정이 적절한지를 파악하기 위하여 본조 사의 설문옹답자와는 다른 새로운 50 명을 대상으로 한 사전조사에서 각각의 정보가 실험자 극으로 제시된 제품을 평가하는데 있어서 얼마나 중요한지룰 7점 리커트척도(1: 중요하지 않다, 7: 중요하다)률 봉해 평가하도록 하고 각각의 단서정보에 대한 T-test롤 수행하여 차이 
를 분석하였다. T-test수행이전에 모두 Levene의 둥분산에 대한 가정을 검정한 결과 브랜드 $(\mathrm{F}=8.791 \mathrm{p}>.05)$, 가격수준 $(\mathrm{F}=9.065, \mathrm{p}>.05)$, 포장방식 $(\mathrm{F}=6.667, \mathrm{p}>.05)$, 판매점포 $(\mathrm{F}=13.120 \mathrm{p}>.05)$ 가 모두 두 모집단의 분산이 동일하다는 귀무가설이 채택되었다. T-test률 수행한 졀과 브랜 드, 가격수준, 포장방식, 판매점포명 모두가 유의확률 $\mathrm{p}<.01$ 수준에서 차이가 있는 것으로 나 타나 외재적 단서정보의 강도조정이 본 연구에 적절한 것으로 탄단되었다.

내재적 속성으로는 25 개의 속성과 관련한 단서정보률 작성한 후 비확률표본추출법중 판단 표본추출법(judgment sampling)을 이용하여 어느 정도 지식이 있다고 파악된 54명의 웅답자들 만을 대상으로 각 정보가 제품평가에 얼마나 중요한지를 7점척도(1: 중요하지 않다, 7: 중요 하다)를 통해 파악하였다. 이렇게 파악된 내재적 단서정보는 강한 내재적 단서정보 4개와 약한 내재적 단서정보 4 개가 선택되었다. 선택된 내재적 단서정보의 강도가 적절한지를 평 가하기 위하여 각 피실헙자가 웅답한 자료를 합계하여 평균으로 나눈 후 두가지 유형의 단 서정보에 대한 T-test를 수행하여 차이를 분석하였다. T-test수행이전에 모두 Levene의 등분산 에 대한 가정을 검정한 결과 $(\mathrm{F}=17.928, \mathrm{p}>.05)$, 두 모집단의 분산이 동일하다는 귀무가설이 채택되었다. T-test수행결과 두 집단의 유의수준 .05에서 웅답평균에 차이가 있는 것으로 나타 나 내재적 단서정보의 강도조정이 본 연구에 적절한 것으로 판단되었다. 여기에서 pretest의 대상은 본 연구와의 오차를 최소한으로 줄이기 위하여 모두 대학생을 대상으로 하였다. 실 헙자극에 이용될 단서정보로서 최종적으로 선택된 외재적 단서와 내재적 단서는 다음 <표 $1>$ 과 같다.

<표 1> 연구 1 의 실험자극으로 제시된 단서정보

\begin{tabular}{|c|c|c|c|}
\hline 단서 & 단서의 강도 & 항목 & $\begin{array}{l}\text { 옹답평균 } \\
\text { (중요도) }\end{array}$ \\
\hline \multirow{2}{*}{$\begin{array}{l}\text { 외재적 } \\
\text { 단서 }\end{array}$} & $\begin{array}{c}\text { 강한 } \\
\text { 외재적 } \\
\text { 단서정보 }\end{array}$ & $\begin{array}{l}\text { 삼성 } \\
\text { 타기업의 동일한 제품보다 35\%눈은 가격수준 } \\
\text { 충겨완화률 위한 독수포장 } \\
\text { 현대백화점에서 판매 }\end{array}$ & 5.14 \\
\hline & $\begin{array}{c}\text { 약한 } \\
\text { 외재적 } \\
\text { 단서정보 }\end{array}$ & $\begin{array}{l}\text { (주)한성 에네턱 } \\
\text { 타기업의 동일한 제품과 동일한 가격수준 } \\
\text { 산업표준에 명시된 포장방식 } \\
\text { E마트에서 판매 }\end{array}$ & 3.10 \\
\hline \multirow{2}{*}{$\begin{array}{l}\text { 내재적 } \\
\text { 단서 }\end{array}$} & $\begin{array}{c}\text { 강한 } \\
\text { 내재적 } \\
\text { 단서정보 }\end{array}$ & 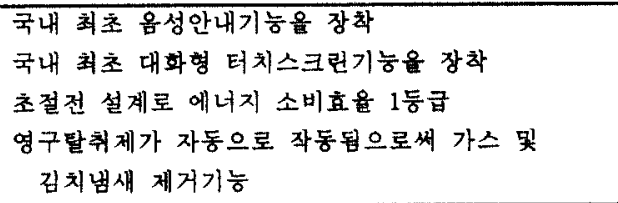 & 5.68 \\
\hline & $\begin{array}{c}\text { 약한 } \\
\text { 내재적 } \\
\text { 단서정보 }\end{array}$ & $\begin{array}{l}\text { 저장실 표면자체가 냉각되는 직접녕각방식 } \\
\text { 김치뽄만 아니라 야채, 과일, 식혜 및 왁유보관가능 } \\
\text { 자연숙성, 저은숙성, 고은숙성의 } 3 \text { 가지 숙성기능 } \\
\text { 손잡이가 있어 용기를 뉩게 꺼낼 수 있음 }\end{array}$ & 2.57 \\
\hline
\end{tabular}

전문성에 대한 평가는 객관적 지식에 대한 설문(Maheswaran and Sterithal 1990)을 기초 로 하여 대상자들을 초보자와 전문가로 분류하였고 중위수분할을 근거로 충 12 개의 김치냉 장고지식설문에 대한 정답의 수를 가지고 비전문가와 전문가로 분류하였다. 
종속변수의 측정을 위해 피실헙자들은 제공된 정보를 읽은 후 제품평가를 위해 제시된네 개의 7점척도(전혀 우수하지 않다-매우 우수하다, 전혀 좋지 않다-매우 줗다, 전혀 호감이 가 지 않는다-매우 호감이 간다, 전혀 구입하고 싶지 않다-매우 구입하고 싶다)에 대하여, 제시 된 상표에 대한 자신들의 태도률 표시하도록 하였다. 이러한 평가척도는 Maheswaran(1994) 이 제조국에 따른 상표의 평가를 수행하면서 이용한 바 있다. 이들 네 개의 다항목척도에 대하여 내부일치성(Internal consistency)을 알아보기 위하여 Cronbach alpha-test를 실시하였다. 분석결과 알파계수값이 모두 0.86 이상인 것으로 나타나 본 분석에 이용하였다. 분석결과는 다음 <표 2>에 나타나 있다.

<표 2 >변수간 신뢰도 검중결과

\begin{tabular}{|c|c|c|c|c|c|}
\hline \multicolumn{2}{|c|}{ 변수 } & $\begin{array}{c}\text { 수정항목간의 } \\
\text { 상관관계 }\end{array}$ & $\begin{array}{c}\text { 항목제외시 } \\
\text { 알파값 }\end{array}$ & $\begin{array}{c}\text { 표준화항목 } \\
\text { 알파값 }\end{array}$ & 알파계수값 \\
\hline 집단A & $\begin{array}{l}\text { Q11 } \\
\text { Q21 } \\
\text { Q31 } \\
\text { Q41 }\end{array}$ & $\begin{array}{l}.7408 \\
.7733 \\
.8448 \\
.7279\end{array}$ & $\begin{array}{l}.8477 \\
.8618 \\
.8322 \\
.8829\end{array}$ & .8973 & .8939 \\
\hline 집단B & $\begin{array}{l}\text { Q12 } \\
\text { Q22 } \\
\text { Q32 } \\
\text { Q42 }\end{array}$ & $\begin{array}{l}.6779 \\
.7916 \\
.8383 \\
.7753\end{array}$ & $\begin{array}{l}.8955 \\
.8529 \\
.8343 \\
.8618\end{array}$ & .8949 & .8963 \\
\hline 집단C & $\begin{array}{l}\text { Q13 } \\
\text { Q23 } \\
\text { Q33 } \\
\text { Q43 }\end{array}$ & $\begin{array}{l}.6952 \\
.7383 \\
.7720 \\
.6631\end{array}$ & $\begin{array}{l}.8333 \\
.8171 \\
.6239 \\
.4971\end{array}$ & .8675 & .8630 \\
\hline
\end{tabular}

\section{3. 가설 1 의 분석결과}

비전문가와 전문가 두 집단이 각각 $\mathrm{A}, \mathrm{B}, \mathrm{C}$ 의 설문지에 웅답한 자료에 대한 ANOVA를 수행함으로써 이루어 졌다. 먼저 전문성의 구분은 모든 웅답자가 김치냉장고에 대한 속성을 묻는 항목에 응답한 값을 기준으로 중위수(median)분할을 근거로 6점 미만을 비전문가로 그리고 6점을 초과하는 웅답자률 전문가로 구분하였다. 종속변수로서 다항목척도인 제품평 가값은 합산평균값을 이용하였다.

\subsection{1 전문가의 경우}

다음은 전문가에 대한 분석결과로 제품평가 옹답치에 대한 등분산분석결과는 다음 <표 $3>$ 과 같다.

<표 3> 전문가집단의 둥분산 검중

\begin{tabular}{|c|c|c|c|c|}
\hline & $\begin{array}{c}\text { Levene } \\
\text { Statistic }\end{array}$ & $\mathrm{df} 1$ & $\mathrm{df} 2$ & Sig. \\
\hline 품질 & 1.794 & 2 & 96 & .172 \\
\hline
\end{tabular}


분석결과 세 모집단의 분산이 동일하다는 귀무가설이 채택되어( $\mathrm{F}=1.794 \mathrm{p}>.05)$, 둥분산이 가정된 하에서 ANOVA를 수행하였다. 분석결과는 다음 <표 4>에 나타나 있다.

<표 4> 전문가집단의 분산분석표

\begin{tabular}{|c|c|c|c|c|c|c|}
\hline \multicolumn{2}{|c|}{} & 제곱합 & $\mathrm{df}$ & 평균제곱 & $\mathrm{F}$ & Sig. \\
\hline \multirow{3}{*}{ 품질 } & 집단간 & 389.723 & 2 & 194.862 & 5.804 & .004 \\
\cline { 2 - 7 } & 집단내 & 3222.9 & 96 & 33.572 & & \\
\cline { 2 - 8 } & 계 & 3612.6 & 98 & & & \\
\hline
\end{tabular}

분석결과 집단간의 차이가 존재하는 것으로 나타나 $(\mathrm{F}=5.804 \mathrm{p}<.05)$ 사후검정을 실시하였으 며 사후검정으로는 scheffe test를 이용하였다. 분석결과는 다옴 <표 $5>$ 와 <표 $6>$ 에 나타나 있다.

<표 5> 전문가집단의 다중비교

\begin{tabular}{|c|c|c|c|c|c|c|}
\hline \multirow{2}{*}{ (I)GROUP } & \multirow{2}{*}{ (J)GROUP } & $\begin{array}{c}\text { 평균편차 } \\
(\mathrm{I}-\mathrm{J})\end{array}$ & \multirow{2}{*}{ 표준오차 } & \multirow{2}{*}{ 유의도 } & \multicolumn{2}{|c|}{$95 \%$ 신뢰구간 } \\
\cline { 5 - 7 } & & & & 하한값 & 상한값 \\
\hline 1.00 & 2.00 & $-3.6565 *$ & 1.386 & .035 & -7.1038 & -.2091 \\
& 3.00 & .7293 & 1.511 & .890 & -3.0268 & 4.4853 \\
\hline 2.00 & 1.00 & $3.6565 *$ & 1.386 & .035 & .2091 & 7.1038 \\
& 3.00 & $4.3857 *$ & 1.428 & .011 & .8359 & 7.9356 \\
\hline 3.00 & 1.00 & -.7293 & 1.511 & .890 & -4.4853 & 3.0268 \\
& 2.00 & $-4.3857 *$ & 1.428 & .011 & -7.9356 & -.8359 \\
\hline
\end{tabular}

<표 6> 전문가집단의 동질하위집단

\begin{tabular}{|c|c|c|c|}
\hline \multirow{2}{*}{ Group } & \multirow{2}{*}{$\mathrm{N}$} & \multicolumn{2}{|c|}{ Subset for alpha $=.05$} \\
\hline & & 1 & 2 \\
\hline 3.00 & 28 & 14.4643 & \\
\hline 1.00 & 31 & 15.1935 & \\
\hline 2.00 & 40 & & 18.850 \\
\hline Sig. & & .880 & 1.000 \\
\hline
\end{tabular}

<표 5>와 <표6>에서는 전문가들만을 대상으로 충 세 개의 집단으로 나누어 내재적 단서 와 외재적 단서의 효과를 파악한 것이다. 집단 1 은 약한 내·외재적 단서에 대한 웅답자집단 
이고 집단 2 는 강한 내재적 단서에 대한 옹답자집단, 그리고 집단 3 은 강한 외재적 단서에 대한 웅답자 집단이다. 위의 분석결과에서 강한 내재적 단서에 노출된 전문가가 다른 두 집 단에 비해 상대적으로 우호적인 소비자반웅을 나타내고 있다(평균차이 : $\mathrm{X}_{2}=18.850 \mathrm{vs}$ $\mathrm{X}_{1}=14.4643, \mathrm{X}_{3}=15.1935$ ). 따라서 전문가는 내재적 단서의 강도는 제품평가에 영향을 미치 고 있으며 반대로 외재적 단서는 제품평가에 영향을 미치지 못하고 있음을 알 수 있다. 따 라서 본 연구의 가설 1-1을 지지한다.

\subsection{2. 비전문가의 경우}

먼저 비전문가의 경우 제품평가 웅답치에 대한 등분산분석결과는 다음 <표7>과 같다.

<표 7> 비전문가집단의 둥분산 검중

\begin{tabular}{|c|c|c|c|c|}
\hline & $\begin{array}{c}\text { Levene } \\
\text { Stat ist ic }\end{array}$ & df 1 & df2 & Sig \\
\hline 품질 & 1.619 & 2 & 108 & .203 \\
\hline
\end{tabular}

분석결과 세 모집단의 분산이 동일하다는 귀무가설이 채택되어( $\mathrm{F}=1.619 \mathrm{p}>.05)$, 둥분산이 가정된 하에서 ANOVA를 수행하였다. 분석결과는 다음 <표 8>에 나타나 있다. 분석결과 집단간의 차이가 존재하는 것으로 나타나 $(\mathrm{F}=4.819 \mathrm{p}<.05)$ 사후검정을 실시하였다. 사후검정 으로는 scheffe test를 이용하였다. 분석결과는 다음 <표 9>와 <표 10>에 나타나 있다.

<표 8> 비전문가집단의 분산분석 결과

\begin{tabular}{|c|c|c|c|c|c|}
\hline & 제곱합 & $\mathrm{df}$ & 평균면차 & $\mathrm{F}$ & Sig. \\
\hline 집단간 & 269.850 & 2 & 134.925 & 4.819 & .010 \\
\hline 집단내 & 3023.897 & 108 & 27.999 & & \\
\hline 계 & 3293.748 & 110 & & & \\
\hline
\end{tabular}

<표 9> 비전문가집단의 다중비교

\begin{tabular}{|c|c|c|c|c|c|c|}
\hline \multirow{2}{*}{ (I GROUP } & \multirow{2}{*}{ (J)GROUP } & \multirow{2}{*}{$\begin{array}{c}\text { 평균편차 } \\
(\mathrm{I}-\mathrm{J})\end{array}$} & \multirow{2}{*}{ 표준오차 } & \multirow{2}{*}{ 유의도 } & \multicolumn{2}{|c|}{$95 \%$ 신뢰구간 } \\
\cline { 5 - 7 } & & & & 하한값 & 상한값 \\
\hline 1.00 & 2.00 & -.2179 & 1.285 & .986 & -3.4074 & 2.9715 \\
& 3.00 & $-3.3333^{*}$ & 1.265 & .035 & -6.4729 & -.1938 \\
\hline 2.00 & 1.00 & .2179 & 1.285 & .986 & -2.9715 & 3.4074 \\
& 3.00 & $-3.1154^{*}$ & 1.177 & .034 & -6.0360 & -.1948 \\
\hline 3.00 & 1.00 & $3.3333^{*}$ & 1.265 & .035 & .1938 & 6.4729 \\
& 2.00 & $3.1154 *$ & 1.177 & .034 & .1948 & 6.0360 \\
\hline
\end{tabular}

* 짐단 $1(1 \mathrm{Group}):$ 약한 내재적 단서*약한 외재적 단서 짐단 2(2Group): 깅한 내재적 단서*약한 외제적 단서 집다 3 (3 Group): 악한 내재적 탄서*강한 외재적 딘서 
<표 10> 동질적 하위집단

\begin{tabular}{|c|c|c|c|}
\hline \multirow{2}{*}{ GROUP } & \multirow{2}{*}{ 관찰치 } & \multicolumn{2}{|c|}{ 하위집단(알파계수 $=.05$ ) } \\
\hline & & 1 & 2 \\
\hline 1.00 & 30 & 15.8333 & \\
\hline 2.00 & 39 & 16.0513 & \\
\hline 3.00 & 42 & & 19.1667 \\
\hline 유의도 & & .985 & 1.000 \\
\hline
\end{tabular}

<표 9>와 <표10>에서는 비전문가들만을 대상으로 촣 세 개의 집단으로 나누어 내재적 단서와 외재적 단서의 효과를 파악한 것이다. 집단 1 은 약한 내외재적 단서에 대한 웅답자 집단이고 집단 2 는 강한 내재적 단서에 대한 웅답자집단, 그리고 집단 3 은 강한 외재적 단 서에 대한 웅답자 집단이다. 위의 분석졀과에서 강한 외재적 단서에 노출된 비전문가가 다 른 두 집단에 비해 상대적으로 우호적인 소비자반웅을 나타내고 있다(평균차이 : $\mathrm{X}_{3}=19.1667$ vs $\mathrm{X}_{1}=15.8333, \mathrm{X}_{2}=16.0513$ ). 따라서 비전문가의 경우에는 전문가와는 달리 내재적 단서의 강도는 제품평가에 영향을 미치지 못하는 것으로 나타나고 있지만 외재적 단 서가 강한 경우에는 좀 더 우호적인 제품평가를 수행하고 있다는 것울 알 수 있다. 따라서 본 연구의 가설 1-1을 지지한다. 결과적으로 본 연구의 가설 1은 지지되었다고 할 수 있다.

\section{4. 연구 2}

\section{1. 단서관련사고 및 조절효과에 대한 가설의 설정}

소비자는 제품의 평가과정에서 외재적 단서나 내재적 단서와 관련된 사고를 동시에 수행 할 것으로 예상되며 이러한 단서관련사고는 제품평가에 있어서 내재적 단서나 외재적 단서 의 효과를 매개할 가능성이 있을 것으로 예상된다(Majeswaran, Mackie, and Chaiken 1992).

전문가들은 내재적 단서를 자세히 처리하고 내재적 단서관련사고를 더욱 할 것으로 예상 된다. 또한 그러한 내재적 단서관련사고는 강한 내재적 단서에 접근가능한 경우 좀 더 우호 적일 것으로 예상된다. 반대로 비전문가는 외재적 단서에 더 큰 정교화를 할 것이고 따라서 외재적 단서관련사고를 더 많이 할 것으로 기대된다. 또한 그러한 경향은 강한 외재적 단서 에 접근가능한 경우 좀 더 우호적일 것으로 예상된다. 이러한 추론에 대한 근거는 본 연구 의 연구1에서 나타난 바와 같이 전문가의 경우 내재적 단서를 대상에 대한 평가기준으로 사 용하고 외재적 단서는 소비자의 평가에 영향을 미치고 있지 못하기 때문이다. 이와는 달리 비전문가의 경우 내재적 단서에는 최소한의 주의만을 하기 때문에 내재적 단서관련사고는 최소화될 것으로 예상된다. 본 연구의 연구 1 의 결과에서는 이러한 추론을 뒷받침해주고 있 
는데 비전문가의 경우 외재적 단서만이 소비자의 평가과정에 영향을 주고 있기 때문이다. 이를 바탕으로 하여 다음 가설을 설정하였다.

가설 2 : 전문가는 내재적 단서정보률 자세히 처리하고 또한 내재적 단서관련사고률 더 않이 할 것이다. 또한 강한 내재적 단서정보에의 접근이 가능한 경우에 좀더 우호적인 내재 적 단서관련사고룰 할 것으로 예상된다.

가설 3: 비전문가는 외재적 단서정보률 자세히 처리하고 또한 외재적 단서관련사고률 더 많이 할 것이다. 또한 강한 외재적 단서정보에의 접근이 가능한 경우에 좀 더 우호적인 외재적 단서관련사고률 할 것으로 예상된다.

언급한 바와 같이 내재적 단서관련사고와 외재적 단서관련사고는 소비자의 제품평가에 영 향을 줄 것으로 기대된다(Maheswaran. Mackie, and Chaiken 1992). 그러나 이러한 단서관 련사고가 제품평가에 직접적으로 영향을 주기도 하지만 그러한 단서사고가 얼마나 우호적으 로 이루어지는가에 따라 단서사고가 제품평가에 미치는 영향을 매개할 것으로 기대된다. 그 것은 단서관련사고가 많다고 하더라도 부정적인 경우에는 제품평가에 부정적인 영향을 미칠 수 있음을 의미하는 것이다. 본 연구의 연구 2 에서는 또한 이러한 매개적 역할에 대해 경 로분석을 통해 검중하고자 한다. 여기에서 전문가의 경우 내재적 단서관련 우호성사고가 그 리고 비전문가의 경우에는 외재적 단서관련 우호성사고가 단서관련사고와 제품평가간의 관 계를 매개할 것으로 기대된다. 이를 바탕으로 다음 가설을 설정하였다.

가설 4 : 전운가의 경우 내재적 단서와 관련된 우호성사고가 내재적 단서관련사고와 제품 평가간의 관계를 매개할 것이다.

가설 $5:$ 비전문가의 경우 외재적 단서와 관련된 우호성사고가 외재적 단서관련사고와 제 품평가간의 관계를 애개할 것이다.

\section{2. 연구의 대상 및 절차}

연구 2 의 절차와 실험자극도 연구 1 의 절차 및 자극과 동일하다. 단서관련사고를 힉득하기 위하여 김치냉장고에 대하여 관심이 있는 총 261 명의 일반 소비자를 대상으로 연구 1 과 유 사하게 집단 $\mathrm{A}$ (약한 내재적 단서*약한 외재적 단서) $\mathrm{B}$ (강한 내재적 단서*약한 외재적 단서) 및 $\mathrm{C}$ (약한 내재적 단서*강한 외재적 단서)에 무작위로 할당되어 실험자극에 대한 노출 이후 에 설문에 참가하였다. 실험에 참가한 피실험자들은 실헙자극으로 제시된 제품에 대하여 각 각 자신들이 느끼는 생각(사고)을 자유롭게 기술하도록 하였다(Weber and Crocker 1983). 이 과정에서 피실험자들은 그들이 실헙자극으로 제시된 김치냉장고에 대한 정보를 담고 있는 광고지를 읽는 동안 김치냉장고 그 자체나 또는 김치냉장고의 상표 어느것이든 상관없이 떠 오르거나 느끼는 생각들올 기술하도록 요구하였다. 이러한 생각들은 두명의 코딩자가 각각 독립적인 판단으로 코딩하였다. 코덩자들은 서로 $98 \%$ 동의하였고 차이가 발생한 항목에 대 해서는 토론을 통해 해결하였다. 코딩과정에서 퍼실험자들이 웅답한 항목올 외재적 단서와 관련된 사고(E)와 내재적 단서와 관련된 사고(I)로 분류하였고(Maheswaran and Chaiken 1991) 분류된 항목의 수를 계산하였다. 또한 각각의 사고들은 또한 긍정적(+), 중립적(0), 그리고 부정적(-)으로 코딩되었다. 예를 들어, 나는 모 기업이 생산한 김치냉장고에 대해 신뢰가 간 
다(E+); 나는 모 기업이 컴퓨터를 생산하고 있는지 궁금하다(E0); 나는 모 기업이 컴퓨터를 생산한다는 것에 대해 회의적이다(E-); 나는 이 제품에 새로 추가된 기능이 아주 우수하다고 생각한다(I+); 나는 이 제품의 기능이 다른 컴퓨터와 다를바 없다고 생각한다(I0); 나는 이 제품의 기능이 다른 컴퓨터보다 못하다고 생각한다(I-)둥이다. 또한 전문성에 대한 측정과 구분 및 제품에 대한 평가도 연구 1 과 동일한 방법을 적용하였다. 다만 연구 1 의 설문지와 다른 항목은 단서에 대한 평가값을 구하기 위하여 각 단서가 제품평가에 얼마나 유용한지에 대하여 7점척도로 측정한 것이다.

가설 4와 5 를 검증하기 위한 사고우호성은 내재적 단서와 외재적 단서 두가지 모두 긍정 적인 사고에서 부정적인 사고를 뺀 차이값을 이용하였다.

\section{3. 분석결과}

\subsection{1. 가설 2 와 3 의 분석}

가설 2와 3의 분석은 웅답자들이 웅답한 단서관련사고의 수에 대하여 T-test와 ANOVA률 수행함으로써 이루어 졌다. 먼저 단서관련사고의 수에 대한 차이를 측정하기 위하여 전체옹 답자를 대상으로 김치냉장고에 대한 지식정도를 측정하여 중위수분할을 통해 비전문가와 전 문가로 구분한 다음 두 집단이 웅답한 단서관련사고의 수에 대하여 T-test를 수행하였다. 먼 저 전문가의 내재적 단서와 외재적 단서관련사고수의 차이에 대한 분석결과는 다음 <표 $11>$ 에 나타나 있다.

<표 11> 전문가집단에 대한 집단통계량

\begin{tabular}{|c|c|c|c|c|c|}
\hline \multicolumn{2}{|c|}{ 단서사고 } & $N$ & Mean & $\begin{array}{c}\text { Std. } \\
\text { Deviation }\end{array}$ & $\begin{array}{c}\text { Std. Error } \\
\text { Mean }\end{array}$ \\
\hline \multirow{2}{*}{ 사고의 수 } & 내재적 & 66 & 1.1515 & 1.3839 & .1703 \\
\cline { 2 - 7 } & 외재적 & 66 & .6667 & 1.0278 & .1265 \\
\hline
\end{tabular}

위의 분석결과표에서 볼 수 있듯이 전문가의 경우 단서관련사고는 외재적 단서관련사고보 다 내재적 단서관련사고를 유의적으로 더 많이 하는 것을 알 수 있다 $(F(1,130)=4.08$, $\mathrm{p}$ <.05). 따라서 본 연구의 가설 2 에서 제시한 바와 같이 전문가는 내재적 단서를 더욱 자세 히 처리한다고 볼 수 있다. 또한 강한 내재적 단서정보에의 접근이 가능한 경우에 좀더 우 호적인 내재적 단서관련사고를 하는지에 대해 검증하기 위하여 내재적 단서강도가 다르게 조작된 자극 $\mathrm{A}$ 와 자극 $\mathrm{B}$ 에 응답한 전문가들만을 대상으로 내재적 단서관련사고의 수에 대한 차이를 검증하였다. 분석결과는 다음 <표 12>에 제시되어 있다.

<표 12> 내재단서의 강도에 따른 전문가집단의 집단통계량

\begin{tabular}{|c|c|c|c|c|c|}
\hline \multicolumn{2}{|c|}{ 자극유형 } & $\mathrm{N}$ & Mean & $\begin{array}{c}\text { Std. } \\
\text { Deviat ion }\end{array}$ & $\begin{array}{c}\text { Std. Error } \\
\text { Mean }\end{array}$ \\
\hline \multirow{2}{*}{ 내재단서 } & 약함 & 14 & .6429 & .9288 & .2482 \\
\cline { 2 - 6 } & 강함 & 18 & 2.4444 & 2.3319 & .5496 \\
\hline
\end{tabular}


위의 분석결과표에서 볼 수 있듯이 전문가의 경우 상대적으로 강한 내재적 단서에 접근가 능한 경우가 그렇지 않은 경우보다 내재적 단서관련사고률 유의적으로 더 많이 하는 것을 알 수 있다(F(1,30)=17.564, $\mathrm{p}<.05)$. 이는 가설 2에서 제시한 바와 같이 전문가의 경우에는 강한 내재적 단서에 접근가능한 경우에 내재적 단서관련사고를 더욱 깊이있게 처리한다는 것을 보여주고 있다고 할 수 있다. 이러한 결과률 바탕으로 하여 본 연구의 가설 2 를 지지 한다.

한편 비전문가의 경우에도 위에서 수행했던 전문가의 경우와 마찬가지로 단서관련사고의 수에 대하여 T-test를 수행하였다. 비전문가에 대한 분석결과는 다음 <표 13>에 나타나 있다.

<표 13> 비전문가 집단에 대한 집단통계량

\begin{tabular}{|c|c|c|c|c|c|}
\hline \multicolumn{2}{|c|}{ 단서사고 } & $N$ & Mean & $\begin{array}{c}\text { Std. } \\
\text { Deviat ion }\end{array}$ & $\begin{array}{c}\text { Std. Er ror } \\
\text { Mean }\end{array}$ \\
\hline \multirow{2}{*}{ 사고의 수 } & 내재적 & 82 & .7073 & .9492 & .1048 \\
\cline { 2 - 6 } & 외재적 & 82 & 1.1098 & 1.1654 & .1287 \\
\hline
\end{tabular}

위의 분석결과표에서 볼 수 있듯이 비전문가의 경우에는 전문가와는 반대로 내재적 단서 관련사고보다 외재적 단서관련사고롤 유의적으로 더 많이 하는 것을 알 수 있다 $(\mathrm{F}(1,162)=4.219, \mathrm{p}<.05)$. 따라서 본 연구의 가설 2 에서 제시한 바와 같이 비전문가는 외재 적 단서를 더욱 자세히 처리한다고 볼 수 있다. 또한 강한 외재적 단서정보에의 접근이 가 능한 경우에 좀더 우호적인 외재적 단서관련사고를 하는지에 대해 검중하기 위하여 내재적 단서강도가 다르게 조작된 자극A와 자극 $\mathrm{C}$ 에 웅답한 비전문가들만을 대상으로 외재적 단서 관련사고의 수에 대한 차이를 검증하였다. 분석결과는 다음 <표 14 >에 제시되어 있다.

<표 14> 외재단서의 강도에 따른 비전문가집단에 대한 집단통계량

\begin{tabular}{|c|c|c|c|c|c|}
\hline \multicolumn{2}{|c|}{ 설문형태 } & N & Mean & $\begin{array}{c}\text { Std. } \\
\text { Deviat ion }\end{array}$ & $\begin{array}{c}\text { Std. Error } \\
\text { Mean }\end{array}$ \\
\hline \multirow{2}{*}{ 외재적 } & 약함 & 31 & 1.5161 & 1.2615 & .2266 \\
\cline { 2 - 6 } & 강함 & 28 & 1.7857 & 1.5719 & .2971 \\
\hline
\end{tabular}

비전문가의 경우에는 위의 분석결과에서 볼 수 있듯이 외재적 단서의 강도가 외재적 단서 관련사고의 수에는 유의수준 .05에서 유의적인 영향을 미치지 못하는 것으로 나타나고 있다 $(\mathrm{F}(1,57)=.385, \mathrm{p}>.1)$. 이 결과는 비전문가의 경우에는 전문가와는 달리 외재적 단서강도의 차이에 의해서 단서관련사고의 수를 증가시키기 보다는 전반적으로 외재적 단서에 많이 의 존하는 것으로 보인다. 이 결과를 바탕으로 하여 본 연구의 가설 3 은 부분적으로 지지되었 다고 할 수 있다.

4.3.2 가설 4 와 5 의 분석

본 연구의 가설 4 와 5 는 전문가와 비전문가가 각각 내재적 및 외재적 단서와 관련된 우 
호성사고가 내재적 단서에 대한 평가와 외재적 단서에 대한 평가가 제품평가에 미치는 영향 을 매개하는지와 관련된 것이다. 본 연구에서는 전문가의 경우에는 내재적 단서와 관련된 우호성사고가 내재적 단서에 대한 평가와 제품평가간의 관계를 매개할 것으로 가정하였고 반대로 비전문가의 경우에는 외재적 단서와 관련된 우호성사고가 외재적 단서에 대한 평가 와 제품평가간의 관계를 매개할 것으로 기대하고 있다. 이를 검중하기 위하여 내재적 및 외 재적 단서에 대한 평가가 제품평가에 미치는 영향을 검증하였고 이들간에 관계에 있어서 내 재적 단서의 우호성사고와 외재적 단서의 우호성사고가 비전문가와 전문가별로 매개효과를 갖는지를 검중하였으며 이를 위하여 비전문가와 전문가별로 분리된 경로분석(path analysis)을 수행하였다. 분석결과는 다음 <그림 1>에 제시되어 있다.

\section{<그림 1-a> 전문가의 경우 경로분석의 결과}

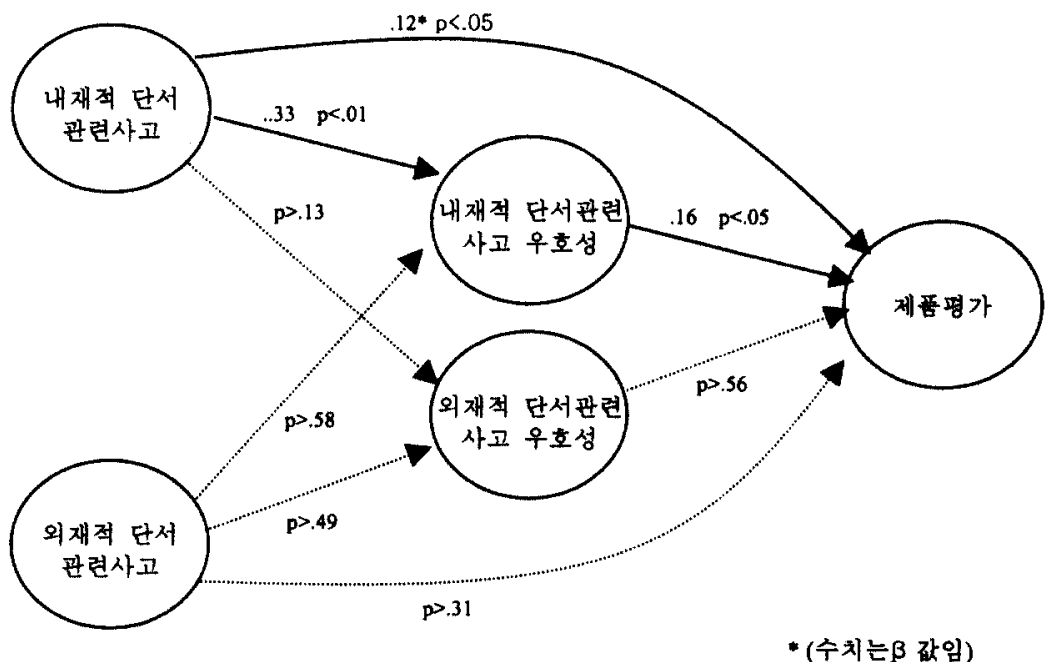

<그립 1-b> 비전문가의 경우 경로분석의 결과

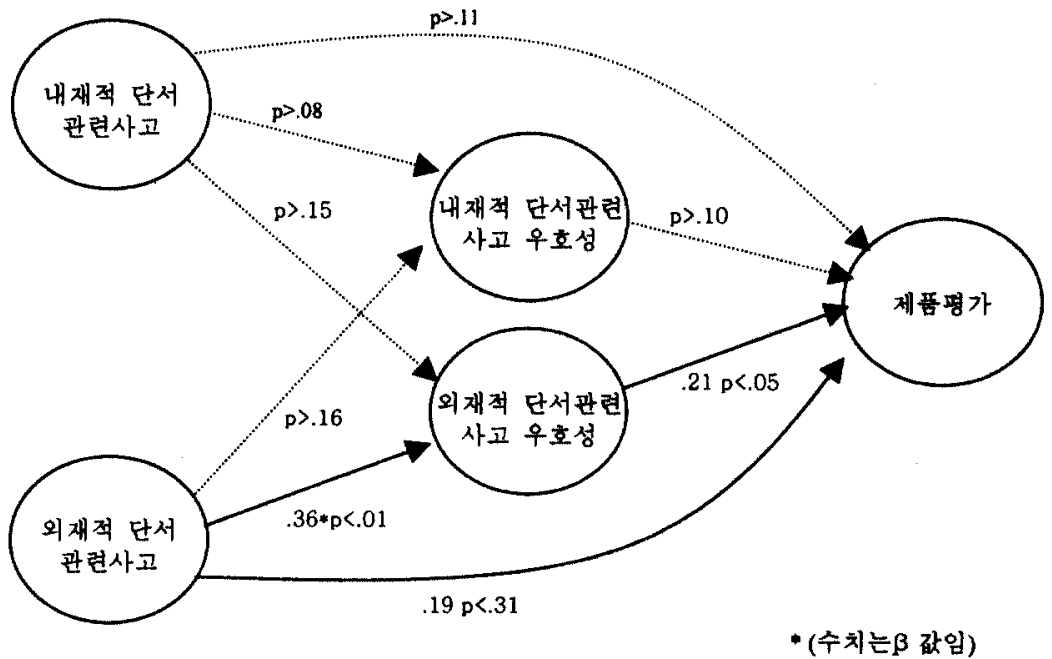


<그림 1-a>의 분석결과에서 전문가의 경우에는 내재적 단서사고가 제품평가에 영향율 미 치고 있으며 동시에 내재적 단서관련사고의 우호성이 내재적 단서사고와 제품평가간의 관계 를 매개하고 있음을 알 수 있다. 그러나 외재적 단서관련사고는 제품평가에 영향을 미치고 있지 못하고 있으며 아울러 외재적 단서관련사고의 우호성도 어떠한 영향을 미치지 못하고 있음올 알 수 있다. 이는 가설 1 과 2 의 결과를 지지하며 좀 더 세부적으로 밝혀주고 있다고 할 수 있다. 따라서 가설 4 를 지지한다. <그림 1-b>의 분석결과는 전문가와는 반대로 비전문 가의 경우에는 내재적 단서관련사고는 제품평가에 영향을 미치지 못하고 있으며 외재적 단 서관련사고만이 제품평가에 영향을 미치고 있다. 이것은 가설 1 을 지지하는 결과라고 볼 수 있다. 또한 가설 5 에서 가정하였둣이 비전문가의 경우에는 외재적 단서관련사고의 우호성이 외재적 단서관련사고와 제품평가와의 관계를 매개하고 있는 것으로 나타나고 있다. 이러한 결과는 가설 3 의 결과를 지지하는 것이며 또한 가설 3 의 내용을 좀 더 세부적으로 밝혀주고 있는 결과라고 할 수 있다.

\section{5. 결 론}

\section{1. 연구의 요약}

본 연구에서는 소비자 톡성변수 중 전문성을 고려한 제품평가에 있어서 외재적 단서와 내 재적 단서가 어떠한 영향올 미치는지 알아보기 위해 실중자료로써 김치냉장고에 대한 외 재적 단서와 내재적 단서를 제공하여 제품평가 과정을 실증 분석하여 검증함으로써 다음과 같은 결론에 도달하였다.

첫째, 외재적 단서와 내재적 단서가 소비자의 전문성 수준에 따른 제품 평가에 미치는 영 향은, 비전문가의 경우 내재적 단서는 제품평가에 영향을 미치지 못하는 것으로 나타난 반 면 외재적 단서는 재품평가를 좀 더 우호적으로 수행하도록 함을 알 수 있다. 전문가의 경 우에는 비전문가와는 달리 외재적 단서는 평가에 영향을 미치지 못하는 반면 내재적 단서는 제품평가에 영향을 미치는 것으로 나타남으로써 소비자의 전문성 수준에 따라 제품평가에 대한 외재적 단서와 내재적 단서의 효과가 각기 다르게 나타나고 있음을 알았다.

둘째, 소비자가 제품을 평가하는 과정에서 외재적 단서나 내재적 단서와 관련된 사고를 수행할 때 전문가의 경우 내재적 단서 관련 사고를 더 많이 함으로써 내재적 단서를 더욱 자세히 처리함을 알 수 있으며 더 나아가 상대적으로 강한 내재적 단서에 접근 가능할수록 그 성향이 중가함을 알 수 있다. 이와 반대로 비전문가의 경우 외재적 단서 관련 사고를 더 많이 함으로써 외재적 단서를 더 많이 처리한다고 볼 수 있으나 전문가와는 달리 외재적 단 서의 강도가 단서관련 사고의 수를 증가시키지는 않는 것올 알 수 있다. 이로써 소비자의 전문성 수준에 따라 제품평가 과정에서 단서와 관련된 사고의 패턴이 다르게 나타나고 있음 을 알 수 있다.

셋째, 전문가와 비전문가가 내재적 단서와 외재적 단서를 이용하여 제품을 평가할 때, 각 각의 단서와 관련된 사고의 우호성이 제품평가에 미치는 영향을 매개한다는 것을 알 수 있 다. 


\section{2. 연구의 시사점}

\subsection{1. 이론적 시사점}

일반적으로 소비자가 상표를 평가할 때 이용하는 기준에는 외재적 단서와 내재적 단서가 있옴은 이미 널리 알려져 있다. 그럼에도 불구하고 아직까지 소비자의 제품평가 과정에서 품질평가의 시그널로서 외재적 단서와 내재적 단서의 작용에 대한 일반화된 결론을 제시하 지 못하고 있는 실정이다. 그것은 전문성과 같은 소비자의 정보탐색 과정에 영향을 미치는 소비자의 특성변수를 고려하지 않고 일반적인 결과를 제시하는 기존연구의 한계에서 비롯된 것이라 할 수 있다. 본 연구에서는 외재적 또는 내재적 단서들이 전문가라는 소비자의 특성 변수에 따라 제품평가 과정에 어떻게 작용하는지를 명학하게 제시하고 있으며 또한 단서 또 는 단서관련 사고의 우호성의 매개효과가 존재함을 보여주고 있다.

\subsection{2. 관리적 시사점}

본 연구의 결과는 효과적인 제품촉진전략을 구축하기 위한 많은 관리적 시사점들을 제시 하고 있다.

첫째, 전문성이라는 소비자 특성변수를 고려할 때 소비자의 구매의도를 형성하기 위하여 적절한 외재적 및 내재적 단서의 제공은 마케팅에서 중요한 마케팅믹스 전략 중의 하나이다. 특히 상표자산(brand equity)이 마케팅에서 중요한 이슈로 부각되고 있는 바와 같이 전문성을 띄지 않는 소비자 집단에 대한 강력한 상표자산은 더욱 우호적인 제품평가률 유도하야여 하 기 때문에 상표자산 구축을 위한 단서의 제공이 전략적으로 이루어져야 한다.

둘째, 본 연구의 결과는 지속적인 광고와 광고컨셉의 중요성을 말하고 있다. 광고는 소비 자들이 제품평가 시 적용하는 스키마의 형성뿐만 아니라 후발업체의 상표를 효과적으로 고 려집합 군(consideration set)에 진입시키는 역할을 하기 때문에 광고가 절실하게 필요하다는 것은 이미 잘 알려진 사실이나 이때 표적시장에 따라 어떤 광고를 해야 할 것인가는 본 연 구의 결과를 활용해야 할 것으로 생각된다. 즉 다시 말해서 광고가 강한 내재적 단서를 제 공하도록 할 것인가 외재적 단서를 제공하도록 할 것인가가 신중하게 고려되어야 한다.

셋째, 본 연구의 결과는 외재적 단서관리의 중요성올 일깨워 주고 있다. 본 연구의 결과에 의하면 소비자의 제품평가 과정은 전문성에 따라 다르게 나타남으로써 비전문가의 경우 강 한 외재적 단서에 의해 제품평가를 좀 더 우호적으로 하고 있기 때문이다. 즉 동둥한 내재 적 단서강도가 제공된 복수의 제품들 중 외재적 단서강도가 강한 제품이 고려대상으로 선택 될 것이기 때문이다.

넷째, 상표가 알려지지 않은 제품에 있어서 내재적 단서에 근거한 사실적 정보전달의 중 요성이다. 연구결과에서는 전문가의 경우 내재적 단서에 따라 더 우호적으로 제품평가를 하 는 것으로 밝혀졌기 때문에 상표가 알려지지 않은 제품(특히 중소기업의 제품)에 있어서 실 질적인 내재적 단서 정보의 전달이 외재적 단서정보의 제공보다 소비자로 하여금 우호적 제 품평가를 하도록 함에 있어 더 효과적일 것이기 때문이다.

다섯째, 본 연구의 결과는 고객설독에 있어서 다른 접근방법을 제공하고 있다. 소비자의 구매전 과정에서 제품평가의 과정은 소비자가 정보처리와 대안의 평가 둥을 통하여 특정상 표를 선택적으로 인식하는 과정이라 말할 수 있다. 소비자는 이 과정을 통하여 구매의사결 정을 할 것이기 때문에 마케터가 소비자를 설득하여 자사상표를 선택하도록 하기 위해서는 소비자의 수준에 맞는 단서를 제공하여야 한다는 것이다. 


\section{3. 연구의 한계점 및 향후 연구방향}

본 연구는 기존의 연구와는 달리 소비자의 전문성올 고려한 제품평가에 있어서 외재적 단 서와 내재적 단서의 호과에 대하여 연구함으로써 소비자의 특성변수를 고려한 복수단서의 효과를 알아쌨다. 그러나 본 연구는 몇 가지 한계점을 가지고 있다.

첫째는, 본 연구에서 이용한 실헙자극은 실제의 광고자극이라기 보다는 본 연구를 위해 연구자가 작성한 것이다. 실헙자극을 실제의 자극과 유사하게 설계되도록 하는 노력은 많이 이루어졌다 하더라도 이러한 실험자극은 실제의 자극과는 차이가 있올 수 있다. 또한 소비 자조사시에 실물울 제공하지 못함으로써 언급된 단서들에 대한 응답자의 시각적 평가에 제 약이 있었을 것으로 판단된다. 따라서 실제자극을 이용하여 본 연구의 결과를 검증해 볼 필 요가 있다.

둘째, 표본수와 실협자극으로 이용한 제품이 적어 본 연구의 결과를 일반화시키기에는 무 리가 따를 것으로 생각된다. 우선 표본수집에 있어서 지역적 분포의 편중이 초래되어 다양 한 웅답을 구하지 못하였다. 또한 다양한 유형의 제품에 대하여 검증하지 못한 것도 본 연 구의 한계점이라고 할 수 있다. 따라서 적정한 수의 표본과 다양한 제품유형에 대한 검중이 이루어진다면 좀 더 일반화된 결과에 도출할 수 있을 것으로 예상된다.

셋째, 본 연구결과는 웅답자의 전문성 이외의 다른 많은 소비자 특성변수들이 고려되지 않은 것으로써 연구의 결과를 일반화시키기에는 많은 부족함이 있다.소비자의 정보처리에 영향을 줄 수 있는 소비자특성변수는 본 연구에서 다루고 있는 전문성이외에도 관여도, 정 보처리동기, 인지욕구, 다양성추구등 많은 요인들이 있으며 이러한 요인들과의 관련성에 대 한 연구도 필요하다.

향후 연구에서 이러한 본 연구의 한계점들을 고려하여 후속적인 연구가 이루어진다면 소 비자의 제품평가과정에서 각각의 단서유형서들이 소비자의 톡성과 어떠한 관련성을 갖는지, 그리고 이를 통해 단서유형이 소비자의 제품평가에 어떠한 영향올 미치는지에 대한 좀 더 명폐한 통찰력을 제공해 줄 수 있을 것으로 예상된다. 


\section{<참고문헌>}

이수열 \& 황창규(1995), “외재적 단서가 서비스평가에 미치는 영향," 광고학연구, 1995년 2월 호 153-193.

이미현 \& 임숙자(1999), “외재적 단서가 의류제품 평가에 미치는 영향," 한국의류학희집, Vol 23. No 8, 1218-1227.

(2001), "여대생의 소비특성과 청바지의 외재적 단서가 제품평가에 미치는 영향," 한국의류학회집, Vol 25. No6, 1091-1099.

김가영(1998), “의류상품평가에 대한 외재적 단서의 영향," 숙명여자대학교 대학원 박사학위 논문.

김영국(1992), “광고에서 주변적 단서가 소비자의 제품에 대한 태도에 미치는 영향," 마케텅 연구, 1999년 제17권 1호(3월) 102-120.

Alba, Joseph W. and J. Wesley Hutchinson(1987), "Dimensions of Consumer Expertise," Journal of Consumer Research, 13(March), 411-454.

Allison, Ralph I. and Kenneth P. Uhl (1964), "Influence of Beer Brand Indentification on Taste Perception," Journal of Marketing Research, 1 (August), 36-39.

Brucks, Merrie(1985), "The Effects of Product Class Knowledge on Information Search Behaviro," Journal of Consumer Research, 12(June), 1-16.

Celsi, Richard L. and Jerry C. Olson (1988), "The Role of Involvement in Attention and Comprehension Processes," Journal of Consumer Research, September, 210-224.

Chase, William G and Herbert A. Simon(1973), "Perception in Chess," Cognitive Psychology, 4(January).55-81.

Cox, Barbara Davis (1967), "Private Versus National Preference Among Lower and Middle-Income Consumers," Journal of Retailing, 4(Fall), 61-72.

Darby, M. and Karni, E. (1973), "Free Competition and Optimal Amount of Fraud, Journal of Law Economics 16; 67-88.

Dick, Alan, Dipankar Chakravarti, and Gabriel Biehal (1990), "Memory Based Inferences During Consumer Choice," Journal of Consumer Research, 17)June), 82-93.

Duhan, Dale F., Scott D. Johnson, James B Wilcox, Gilbert D. Harrell(1997), "Influences on Consumer Use of Wordof Mouth Recommendation Sources," Journal of Academy of Marketing Science, 25 (Fall), 283-295.

Duncan. Calvin P. and Richard W. Olshavsky(1982), "Extemal Search: The Role of Consumer Beliefs," Journal of Marketing Research, 19(Feb).

Hong, Sung-Tai and Robert S. Wyer (1989), "Effects of Contry-of-Origin and Product-Attribute Information on Product Evaluation: An Information Processing Perspective," Journal of Consumer Research, 16(September), 175-187.

Jacoby, Jacob, Jerry Olson, and Rafael Haddock (1971), "Price, Brand Name and Product Composition Characteristics as Determinants of Perceived Quality," Journal of Applied Psychology, 55(December), 570-79. , George J. Szybillo, and Jacqueline Busato-Schach (1977), "Information Acquisition Behavior in Brand Choice Situations," Journal of Consumer Research, 3 (March), 209-216.

Johnsons, E. J. \& J. E. Russo(1984), "Product Familarity and Learning New Information", Journal of Marketing Research, 11 ((June). 542-550.

Leavitt, Harold J. (1954), "A Note on Some Experimental Findings About The Meaning of Price," Journal of Business, 27 (July), 205-10.

Maheswaran, Durairaj and Brian Sternthal(1990), "The Effects of Knowledge, Motivation, and Type of Message on Ad Processing and Product Judgments," Journal of Consumer Research, 17(June), 66-73. and Shelly Chaiken (1991), "Promoting Systematic Processing in Low-Motivation Settings: Effect of Incongruent Information on Processing and Judgment," Journal of Personality and Social Psychology, 61(July), 13-25. 
, Diane M. Mackie, and Shelly Chaiken (1992), "Brand Name as a Heuristic Cue: The Effects of Task Importance and Expectancy Confirmation on Consumer Judgments," Journal of Consumer Psychology, 1(4), 317-336.

(1994), "Country of Origin as a Stereotype: Effects of Consumer Expertise and Attribute Strength on Product Evaluations," Journal of Consumer Research, 2 I(September), 354-365.

McDaniel, Carl and R.C. Baker (1977), "Convenience Food Packaging and the perception of Product Quality," Journal of Marketing, 41 (October), 57-58.

Milgrom and Roberts (1986), "Price and Advertising Signals of Product Quality, JPE, 796-821.

Miyake, Naomi and Donald A. Norman(1979), "To Ask a Question, One Must Know Enough to Know What is Not Known," Journal of Verbal Learning and Verbal Behavior, 18(June), 102-110.

Meyers-Levy, Joan and Alice M. Tybout (1989), "Schema Congruity as a Basis for Product Evaluation," Journal of Consumer Research, 16(June), 39-54.

Nelson, Phillip (1970), "Information and Consumer Behavior," Journal of Political Economy 78(March/April):311329.

Olson, Jerry C.(1972), "Cue Utilization in the Quality Perception Process: A Cognitive Model and an Empirical Test," doctoral dissertation, Purdue University. and Jacob Jacoby (1973), "Cue Utilization in the Quality Perception Process," in Processings 3rd Annual Conference, M. Venkatesan, ed. Chicago: Association for Consumer Research, 167-79. (1976), "Price as an Informational Cue: Effects on Product Evaluations," Working Series in Marketing Research, College of Business Administration, The Pennsylvania State University, Paper No. 43(May). and Parker Lessig (1981), "Familiarity and Its Impact on Consumer Decision Biases and Heuristics," Journal of Consumer Research, 8 (September), 223-230.

Park, C. Whan and V. Parker Lessig (1981), "Familiarity and Its Impact on Consumer Decision Biases and Heuristics," Journal of Consumer Research, 8 (September), 223-230.

Peterson, Robert A. (1977), "Consumer Perceptions as a Function of Product Color, Price and Nutrition Labeling," in Advances in Consumer Research, Vol. 4, W.D. Perreault, Jr., ed. Atlanta: Association for Consumer Research, 61-63.

Petty, Richard E. and John T. Cacioppo (1981), "Central and Peripheral Routes to Persuasion: Applications to Advertising," Advertising and Consumer Psychology, L. Percy and A. G. Woodside, eds., Lexington, MA: Lexington Books, 3-24.

Rao, Akshay R. and Kent B. Monroe(1988), "The Moderating Effect of Prior Knowledge on Cue Utilization in Product Evaluations," Journal of Consumer Research, 19(Sep), 253-264.

(1989), "The Effects of Price Brand Name, and Store Name on Buyers' Perceptions of Product Quality: An Integrative Review," Journal of Marketing Research, 26(August), 351-57.

Schacter, Daniel L.(1983) "Feeling of Knowing in Episodic Memory," Journal of Experimental Psychology : Learning Memory and Cognition, 9 (Oct), 39-54.

Simonson, Itamar (1989), "Choice Based on Reasons: The Case of Attraction and Compromise Effects," Journal of Consumer Research, 17(September), 158-74.

Sujan, Mita (1985), "Consumer Knowledge: Effects of Evaluation Strategies Mediating Consumer Judgments," Journal of Consumer Research, 12 (June), $31-46$.

Szybillo, George J. and Jacob Jacoby (1974), "Intrinsic vs. Extrinsic Cues as Determinants of Perceived Product Quality," Journal of Applied Psychology, 59(February), 74-78.

Urbany, Joel E., Peter R. Dickson and William L. Wilkie(1989), "Buyer Uncertainty and Information Search," Journal of Consumer Research, 16 (Sep), 208-215.

Weber, Renee and Jennifer Crocker (1983), "Cognitive Processes in the Revision of Stereotypical Beliefs," Journal of Personality and Social Psychology, 45 (November), 961-977.

Wheatley, John J., John S.Y. Chiu, and Arieh Goldman (1981), "Physical Quality, Price and Perceptions of Product Quality: Implications for Retailers," Journal of Retailing, 57(Summer), 10-116.

Wolinsky, Asher (1987), "Brand Names and Price Discrimination," Joumal of Industrial Economics, 35 (March), 255-68.

* 교신저자 